\title{
Low concentration of BPA induces mice spermatocytes apoptosis via GPR30
}

\author{
Chaoliang Wang ${ }^{1, *}$, Jianxiang Zhang ${ }^{2, *}$, Qi Li ${ }^{1, *}$, Tianbiao Zhang ${ }^{1, *}$, Zishi Deng ${ }^{3, *}$, \\ Jing Lian ${ }^{1}$, Donghui Jia ${ }^{1}$, Rui Li ${ }^{1}$, Tao Zheng ${ }^{1}$, Xiaoju Ding ${ }^{1}$, Fan Yang ${ }^{1}$, Chao Ma ${ }^{1}$, \\ Rui Wang ${ }^{1}$, Weixing Zhang ${ }^{1}$ and Jian Guo Wen ${ }^{1}$ \\ 1Department of Urology, The First Affiliated Hospital of Zhengzhou University, Zhengzhou, Henan Province, China \\ ${ }^{2}$ Department of Breast Surgery, The First Affiliated Hospital of Zhengzhou University, Zhengzhou, Henan Province, China \\ ${ }^{3}$ No. 1 Middle School of Yiyang, Yiyang, Hunan Province, China \\ ${ }^{*}$ These authors have contributed equally to this work
}

Correspondence to: Jian Guo Wen, email: wenjg@hotmail.com

Keywords: BPA, GPR30, Erk1/2, EGFR-MAPK pathway, spermatocyte apoptosis

Received: December 05, 2016

Accepted: March 13, 2017

Published: April 07, 2017

Copyright: Wang et al. This is an open-access article distributed under the terms of the Creative Commons Attribution License 3.0 (CC BY 3.0), which permits unrestricted use, distribution, and reproduction in any medium, provided the original author and source are credited.

\section{ABSTRACT}

Bisphenol A (BPA) acts as xenoestrogen and has a great impact on disorders of human reproductive system. However, the mechanism through which BPA can affect human testicular function remains to be identified. GPR30 is a novel membrane estrogen receptor with high-affinity and low-capacity binding to estrogens. We demonstrated that estrogen receptor a (ERa), estrogen receptor $\beta$ (ERß) as well as GPR30 are expressed in mouse spermatocyte-derived GC-2 cells using Real-time PCR. We treated the cells with different doses of BPA and found that even low doses of BPA can inhibit GC-2 cell growth using MTT assay. To make sure which receptor is responsible for the biological function of BPA, we used ER down-regulator ICI and indicated that BPA could bind to GPR30. We also observed that BPA was able to induce Erk1/2 phosphorylation in GC-2 cells and proved that this process was mediated by GPR30-related EGFR-MAPK pathway using western blot. By Real-time PCR, we found that the expression of C-Fos was up-regulated and Cyclin D1 gene was downregulated, in the presence of BPA and ICI. The results of MTT assay, comet assay and flow cytometry indicated that the activation of GPR30 induced by BPA inhibited the cell growth and induced cell apoptosis and ICI, GPR30 siRNA, EGFR inhibitor (AG), and MAPK (PD) inhibitor could partially reverse this effect. Immunohistochemistry on the testis of BPA -damaged mice showed that BPA induced spermatocyte apoptosis without affecting the seminiferous tubules and spermatocyte. In conclusion, BPA triggered spermatocyte apoptosis via GPR30.

\section{INTRODUCTION}

It has been demonstrated that many man-made chemicals presented in food and environment are hormone-like pollutants, which can disrupt the endocrine systems of animals and hence are called environmental endocrine disrupting chemicals (EDCs) [1-3]. Most of the EDCs act as xenoestrogen and exhibit the abilities to mimic, antagonize, or alter the action of endogenous estrogen, and then jeopardize the reproductive capacities of various animals [4-6]. Bisphenol A (BPA), the major xenoestrogen generated by human activities, was broadly distributed in environment.

BPA is a high production volume chemical used in the manufacture of polycarbonate plastics and epoxy resins, which can be used in baby and water bottles, food container linings, beverage cans, medical tubing, dental fillings and other applications [7, 8]. Once it has contaminated the environment, BPA is expected to be more persistent in water and soil [9]. Dietary ingestion is considered the primary source of general population exposure to BPA. Other exposure sources may include 
water, air, and dust [10-13]. As a result, BPA exposure is widespread in the general populations.

BPA has been shown to alter endocrine function through multiple pathways [15]. In experimental animal studies, BPA treatment has been shown to accelerate growth and puberty, to disrupt embryonic development [16], and to induce aneuploidy [17]. BPA levels were positively correlated to the levels of testosterone and androstenedione, suggesting an interaction between androgen and the metabolism of BPA [18]. BPA has also been reported in vitro and in vivo studies to affect the male reproductive system including testes, epididymis, seminal vesicles, and prostate gland [19-23]. These lines of evidences strongly suggested that BPA can harm human reproductive health by acting as an endocrine disruptor.

Many studies have indicated that estrogens have a role in the regulation of testicular function. The absence of estrogen receptors (ERs) causes adverse effects on spermatogenesis and steroid genesis [24-26]. Xenoestrogens can mimic or antagonize the activity of physiological estrogens and have also been shown to affect testicular gene expression [24-27]. The suggested mechanism of xenoestrogen is thought to exert their estrogenic effects primarily by binding to the ER [28-30], which is belong to the nuclear receptor superfamily [31-33]. The mechanism by which BPA exerts its biological actions has been proposed. BPA should mimic or compete with endogenous estrogens, binds to both estrogen receptors (ERs) $\alpha$ and $\beta$ (ER $\alpha$ and ER $\beta$ ), which have been reported as the foremost receptors $[8,15,34-36]$. So, the research has mainly focused on the ability of BPA to affect specific cells through binding these nuclear receptors, although the binding affinity of BPA to estrogen receptor- $\alpha(E R \alpha)$ or $E R \beta$ is 10,000-and 1,000-fold lower than that of estradiol (E2), respectively [37].

Recently, a large amount of evidence has demonstrated that estrogens not only can function through the classic genomic mechanism mediated by ERs but also can trigger rapid responses that involve transduction pathways through the non-genomic mechanism [38]. Some researches found that the G protein-coupled receptor-30 (GPR-30), a seven-transmembrane receptor structurally unrelated to the nuclear ERs, mediates rapid actions of estrogens [39-43]. The discovery of GPR30 has generated a great deal of interest to toward the identification of unknown functions and mechanisms triggered by estrogen outside the nucleus.GPR30 is a possible candidate for rapid estrogen signaling based on the observations that it mediates Erk activation and c-fos expression in an ERindependent manner [42, 44]. Some evidence suggests that BPA also binds to GPR30 and mediates Erk activation $[45,46]$. However, the mechanisms by which BPA can bind to GPR30 and influence male fertility and spermatogenesis remain uncertain. Therefore, it is reasonable to hypothesize that BPA binds GPR30 to mediate non-genomic estrogenic actions and thus to alter these rapid signals. The aims of the present study are to investigate the biological function and signaling pathway of GPR30 influenced by BPA in mice spermatocyte.

\section{RESULTS}

\section{The expression of estrogen receptors in GC-2 cell lines}

To define ERs expression in mouse spermatocyte derived cell line, we analysed the relative mRNA expression levels of ER $\alpha, E R \beta$ and GPR30 in cultured GC-2 cell lines using real-time PCR. The results demonstrated that GC-2 cells express both ERs isoforms as well as GPR30, while the level of ER $\beta$ isoforms was weaker compared to that of ER $\alpha$ or GPR30 (Figure 1A). We also confirmed the result by Western blot analysis, using specific antibodies against the ER $\alpha, E R \beta$ and GPR30 isoforms (Figure 1B).

\section{Low dose of BPA induced inhibition of GC-2 cell growth}

To investigated the biological function of BPA in GC-2 cells, we treated the cells with multiple doses of BPA for $96 \mathrm{~h}$, ranging from $1 \mathrm{nM}$ to $1 \mu \mathrm{M}$. It showed that BPA inhibited GC-2 cell growth and this effect was dose-dependent (Figure 2). The half-maximal inhibitory concentration $\left(\mathrm{IC}_{50}\right)$ of BPA was almost $0.1 \mu \mathrm{M}$. We considered that low dose of BPA could inhibit GC-2 cell growth.

\section{Activate phosphorylation of Erk1/2 by BPA in mouse GC-2 cells}

Estrogens and xenoestrogens were shown to generate a rapid signal via second messengers, such as $\mathrm{Ca}^{2+}$, cAMP and G-proteins, which in turn activate various downstream kinases [47]. To evaluate whether BPA is involved in the rapid cellular response and exerts the estrogenic activity, we investigated the effect of BPA in mouse GC-2 cells on p42/44 MAPK (Erk1/2) phosphorylation. Using increasing doses of BPA( $1 \mathrm{nM}$ $-1000 \mathrm{nM}$ ) for $30 \mathrm{~min}$, we observed that BPA was able to induce Erk1/2 phosphorylation in GC-2 cells, with $100 \mathrm{nM}$ being the most effective concentration (Figure 3A, 3B).

To investigate the receptor-mediated pathway, GC-2 cells were treated for $30 \mathrm{~min}$ with $10 \mu \mathrm{M}$ ICI 182,780 (ICI), the classical ER antagonist. We investigated the time course of Erk1/2 activation by BPA $(100 \mathrm{nM})$ and found that induction occurs rapidly with a peak at $5 \mathrm{~min}$ (Figure 3C, 3D).

It supported that BPA stimulates the phosphorylation mediated by non-classical receptors and this effect is doseand time- dependent. 


\section{BPA-induced Erk1/2 activation is mediated by GPR30 through EGFR-MAPK pathway in GC-2 cells}

To further characterize the role and function of the novel estrogen receptor GPR30, in the BPA-induced activation of Erk1/2, we carried out small interfering RNA (siRNA) experiments. The expression of GPR30 protein was reduced in GC-2 cells transfected with Gpr30 siRNA (Figure 4A and 4B). When the expression of Gpr30 was reduced with specific siRNA, the BPA-induced activation of Erk1/2 was completely abolished (Figure 4C and 4D). Furthermore, BPA-induced activation was completely abolished in the presence of $10 \mu \mathrm{M}$ MEK inhibitor PD98059 (PD) or $10 \mu \mathrm{M}$ EGFR inhibitor AG1478 (AG). Therefore, the results suggested that the expression of GPR30 is necessary for the BPA-induced activation of Erk1/2. EGFR-MAPK pathway is involved this process.

\section{BPA altered the expression level of $c$-Fos mRNA in $\mathrm{GC}-2$ cells}

c-Fos gene participates in the regulation of cell cycle [48]. And Cyclin D1 gene is an essential cell cycle regulatory molecule. Therefore, we evaluated the mRNA expression levels of these targets using qPCR and chose $\beta$-actin as the control. The results in Figure 5 showed that the expression of $c$-Fos was up-regulated and Cyclin D1 gene was down-regulated, in the presence of BPA and ICI. And in other cases the expression levels of these two genes did not change.

\section{BPA inhibits GC-2 cell growth though EGFR- MAPK pathway mediated by GPR30}

To confirm the hypothesis that whether BPA inhibited GC-2 cell growth though EGFR-MAPK pathway mediated by GPR30, MTT assay was performed. We monitored the absorbance of formazan which indirectly reflected cell activity and cell population. BPA slowed down the cell growth after $48 \mathrm{~h}$. The activation of GPR30 induced by BPA inhibited the cell growth and ICI. GPR30 siRNA, EGFR inhibitor (AG) and MAPK (PD) inhibitor could partially reverse the effect (Figure 6).

\section{BPA induce GC-2 cells apoptosis though EGFR- MAPK pathway mediated by GPR30}

BPA could inhibit GC-2 cells proliferation, however, the reason is unclear. Comet assay could intuitively show the damaged DNA, and flow cytometry could determine the apoptosis cells. The cells were treated as described above. Damaged- DNA was examined by comet assay (Figure 7A and 7B) and apoptosis cells were examined by flow cytometry (Figure 7C). In these results, we inferred that BPA could lead to GC-2 cells apoptosis, and the process was though the EGFR-MAPK pathway, mediated by GPR30.

\section{BPA caused mice spermatocyte apoptosis}

The previous results did not provide information on the biological effect of BPA in vivo. It is necessary to performed on the live animals. The BPA-damaged model in mice was built. Immunohistochemistry on mice testis indicates that BPA induce spermatocyte apoptosis significantly, without affecting the seminiferous tubules and spermatocyte (Figure 8). Thus, it prompts that BPA, one of EDCs, could harm reproductive system.

\section{DISCUSSION}

BPA, one of the EDCs, has a great impact on human's endocrine system today. Low concentration of BPA is involved in mediating cell proliferation of pancreatic islet, endothelium, breast, pituitary gland, and prostate tissues [15, 47, 49]. BPA acts as xenoestrogen, in which the ability to bind ERs is approximately $1000-10,000$ times less than that of natural estrogens $[50,51]$. It has been well known that estrogens disrupt
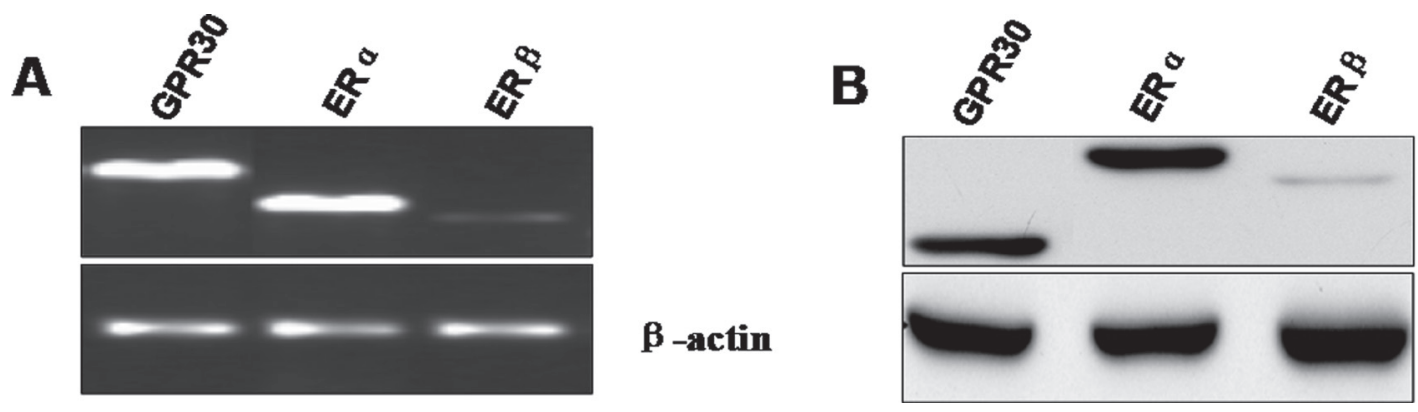

\section{GAPDH}

Figure 1: Expression of estrogen receptors at mRNA and protein levels in the mouse GC-2 cells. (A) ER $\alpha$, ER $\beta$ and GPR30 mRNA expression in GC-2 cells was analyzed by real-time PCR. The PCR products were resolved on 1\% agarose gel electrophoresis and visualized by ethidium bromide staining. $\beta$-actin was used as control gene. (B) Western blot analysis of ERs was performed on $30 \mu \mathrm{g}$ of total proteins extracted from GC-2 cells. Specific antibody for ER $\alpha$, ER $\beta$ and GPR30 are representative of three independent experiments with similar results. GAPDH was used as a loading control. 
human testicular function, mediated by ERs [24-26]. BPA has been usually reported to induce the human reproductive system disorders [52-55].

GPR30 is a novel membrane ER [42] with highaffinity and low-capacity binding to estrogens [43]. In present studies, GC-2 cells expressed ERa and ERb as well as GPR30. It is difficult to make sure which of the three receptors is responsible for the BPA biological action. To eliminate the interruption of ERs, we used selective ERs down-regulator ICI to inhibit the contaction of BPA and ERs. It turned out that BPA should bind to GPR30 to activate the rapid phosphorylation of Erk. GPR30 can mediate the immediate activation of Erk through EGFR [56]. As shown in Figure 3C, our data indicated that the phosphorylation of Erk was activated through EGFR-MAPK pathway mediated by GPR30, which were validated by siRNA and a series of EGFRMAPK inhibitors.

Furthermore, as the similar methods treated, we investigated the relative expression levels of downstream genes $c$-Fos and Cyclin D1. c-Fos gene is a proto-oncogene upregulated by numerous stimuli that enhances its expression and interacts with c-JUN to form heterodimers that regulate cell proliferation and differentiation $[39,56]$. Cyclin D1 promotes the G1 to S phase transition in cell cycle, and it plays a specific role in mitosis [57]. In this study, low concentration of BPA increased $\mathrm{c}$-fos gene expression and down-regulated the expression of Cyclin D1 through EGFR-MAPK pathway. We concluded that BPA inhibits growth of the cells. Then, the comet assay and flow cytometry verified that BPA could induce GC-2 cells apoptosis. Thus, the mechanism of BPA in decreasing GC-2 cells proliferation was proposed as follows: low concentration of BPA could bind to membrane GPR30 and activate the EGFR-MAPK pathway, which caused the activation of $c$-Fos gene and the inhibition of cell-cycle gene Cyclin D1.

We also implemented animal experiment to confirm this speculation. The results proved that BPA triggered spermatocyte apoptosis via GPR30, while it didn't alter the morphological structure of mouse seminiferous tubules.

\section{MATERIALS AND METHODS}

\section{Cell cultures and treatments}

GC-2 cells (a mouse spermatocyte-derived cell line; American Type Culture Collection, Manassas, VA) were cultured in DMEM growth medium supplemented with $10 \%$ fetal bovine serum (FBS), $1 \%$ glutamine, and $1 \%$ penicillin/streptomycin (pen/strep) (Invitrogen, USA). Cells were maintained in growth medium for $48 \mathrm{~h}$ and then starved for $24 \mathrm{~h}$ using DMEM medium supplemented with $1 \% \mathrm{pen} / \mathrm{strep}$ before being treated. Cells were cultured in $60-\mathrm{mm}$ dishes $\left(1 \times 10^{6}\right.$ cells $)$ for RNA and protein extraction, and in 12-well plates for cell proliferation $\left(2 \times 10^{5}\right.$ cells $)$ assay. Treatments were performed at different times using: ICI 182780 (Sigma, USA), siRNA (Qiagen, Germany), PD98059 (Promega, USA), AG1478 (Sigma, USA), Bisphenol A (Sigma, USA).

\section{RNA extraction, cDNA synthesis and PCR reaction}

\section{Total RNA extraction}

Total RNA was extracted from cell cultures using the Trizol commercial kit (Invitrogen, USA) according to the manufacturer's protocol. Possible genomic

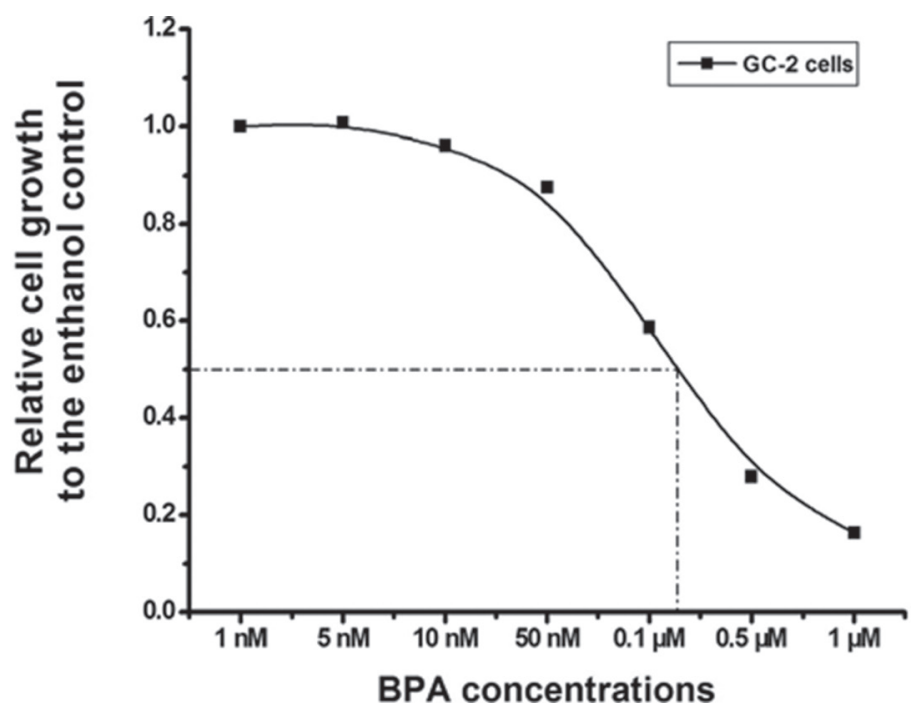

Figure 2: Dose-dependent inhibition of GC-2 cells growth induced by BPA. GC-2 cells planted in 96-well plate were treated with $1 \mathrm{nM}-1 \mu \mathrm{M}$ BPA for $96 \mathrm{~h}$, and control cells were treated with ethanol. Cell growth relative to that of the control was plotted against the concentrations of BPA using sigmoid curve fitting and $\mathrm{IC}_{50}$ was determined. Here, BPA induced a dose-dependent inhibition of growth in CC-2 cells and $0.1 \mu \mathrm{M}$ was closer to $\mathrm{IC}_{50}$. 
DNA contamination was removed from the total RNA preparation using DNA-free ${ }^{\mathrm{TM}}$ Kit (Applied Biosystems, Ambion, AM1906). The final content of RNA was assayed with NanoDrop Spectrophotometer ND-1000 (Saveen Werner, Limhamn, Sweden), and the quality was checked by electrophoresis through agarose $1 \%$ gels stained with ethidium bromide. Only samples that were not degraded and showed clear $18 \mathrm{~S}$ and $28 \mathrm{~S}$ bands under ultraviolet light were used for RT-PCR.

\section{cDNA synthesis}

Intact RNA was converted to cDNA by reverse transcription using TaqMan Reverse Transcription Regents (Applied Biosystems, Foster City, CA, USA), according to protocols from the manufacturer. The final concentration of cDNA was $10 \mathrm{ng} / \mathrm{ml}$ verified by NanoDrop Spectro photometer ND-1000. The samples were stored at $-20^{\circ} \mathrm{C}$ until further used.

\section{Real-time PCR reaction}

The expression of selected genes was quantified by real-time PCR using ABI PRISM 7500 sequence detection system (Applied Biosystems, USA) following

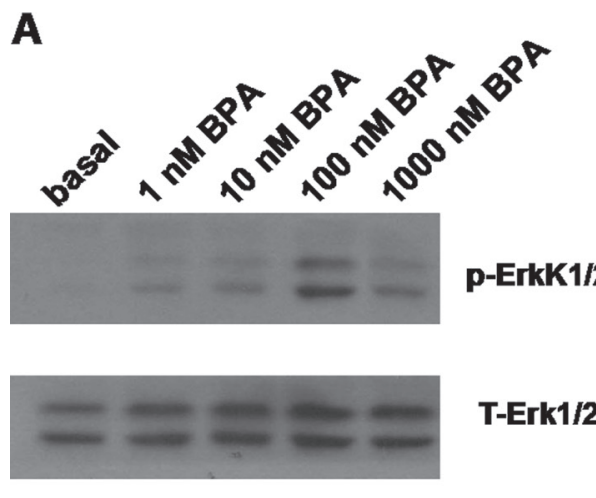

C BPA $\mathrm{BPA}+\mathbf{I C I} \mathbf{I C I}$

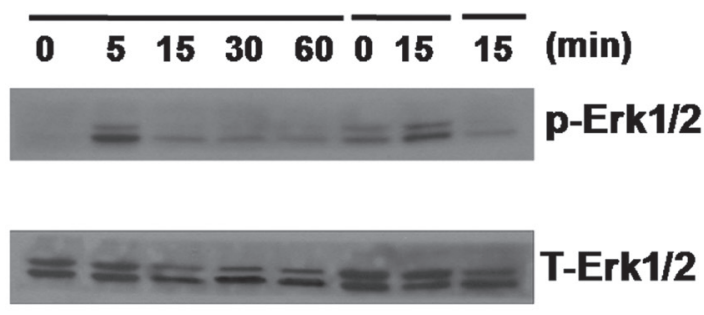

the manufacturer's instructions. PCR was performed on 200 ng cDNA using specially primers. Gene-specific primers were designed using Primer premier 5.0 software and primer sequences are listed as follows: c-Fos (forward, 5'-GAGGAGGGAGCTGACAGATACACT-3'; reverse, 5'-GATTGGCAATCTCAG TCTGCA A-3'); Cyclin D1 (forward, 5'- TCCGCA AGCATGCACAGA-3'; reverse, 5'- GGTGGGTTGGAAATGAACTTC A-3'). We used $\beta$-actin (forward, 5'- CTGGAACGGTGAAGGTGACA-3'; reverse, 5'- AAGGGACTTCCTGTAA-3') as a reference gene. We performed quantitative real-time PCR using Immolase heat-activated Taq DNA polymerase (Invitrogen, USA). SYBR Green I (Invitrogen, USA) was used for detecting fluorometric product. Cycle parameters were $96^{\circ} \mathrm{C}$ for $15 \mathrm{~min}$ for polymerase activation, followed by 40 cycles of $95^{\circ} \mathrm{C}$ for $15 \mathrm{sec}, 57^{\circ} \mathrm{C}$ for $15 \mathrm{sec}$, and $72^{\circ} \mathrm{C}$ for $30 \mathrm{sec}$, with an optical read stage at $83.5^{\circ} \mathrm{C}$ for $6 \mathrm{sec}$.

\section{Western blot analysis}

Cells were grown in 10-cm dishes after treatment and GC-2 cells were washed in PBS and homogenized in buffer (10 nM Tris-HCl, $5 \mathrm{mM}$ EDTA, $50 \mathrm{nM} \mathrm{NaCl}$, $50 \mathrm{mM}$ sodium fluoride, $30 \mathrm{mM}$ sodium pyrophosphate, $1 \%$ Triton-X, $200 \mu \mathrm{M}$ sodium orthovanadate, $1 \mathrm{mM}$

\section{B}

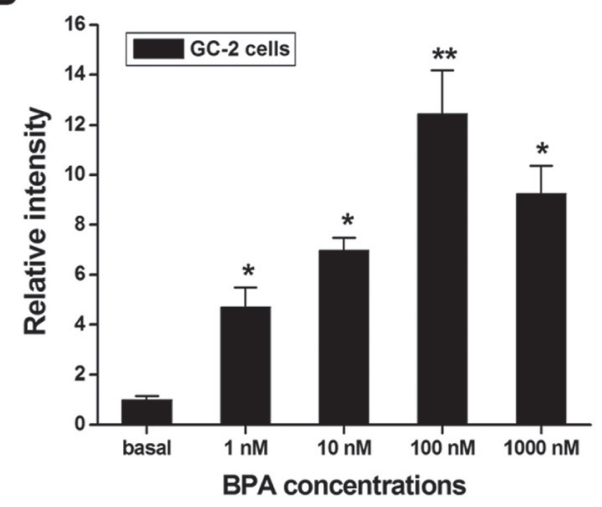

D

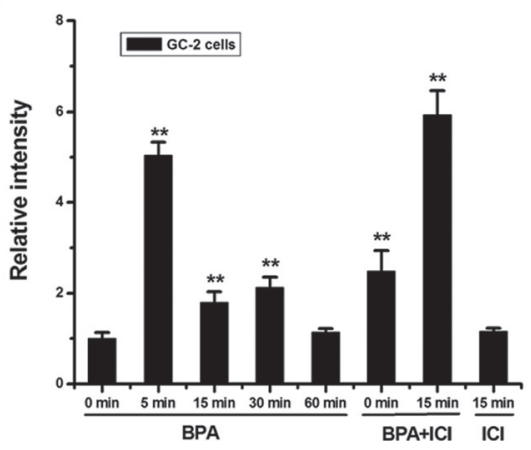

Figure 3: Effects of BPA on Erk1/2 activation in GC-2 cells. (A, B) BPA-induced activation of Erk1/2. Cells were treated for $30 \mathrm{~min}$ with the indicated concentrations of BPA, and the phosphorylation of Erk1/2 were examined by western blot. (C, D) Cells were treated for the indicated times with $100 \mathrm{nM}$ of BPA. For the treatment with an estrogen antagonist, cells were pretreated with $10 \mu \mathrm{M}$ ICI for $30 \mathrm{~min}$ and then treated with $100 \mathrm{nM}$ BPA for 5 or $15 \mathrm{~min}$. Western blot analyses of the amounts of phospho-Erk1/2 (p-Erk1/2) and total Erk1/2 (T-Erk1/2) were performed on $50 \mu \mathrm{g}$ of total proteins extracted from GC-2 cells untreated (basal) or treated as indicated. Blots are representative of three independent experiments with similar results. $* * P<0.01$. 

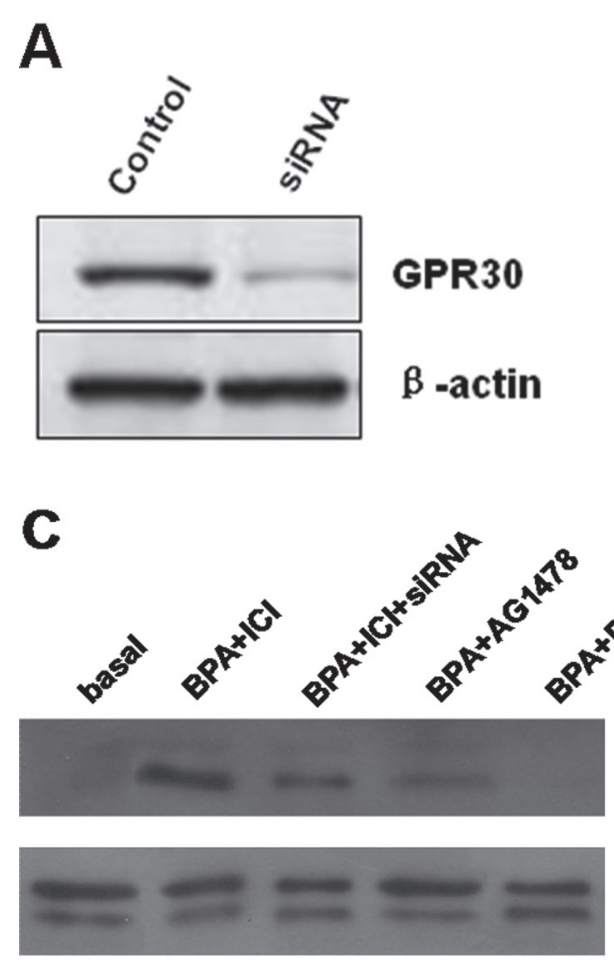

B
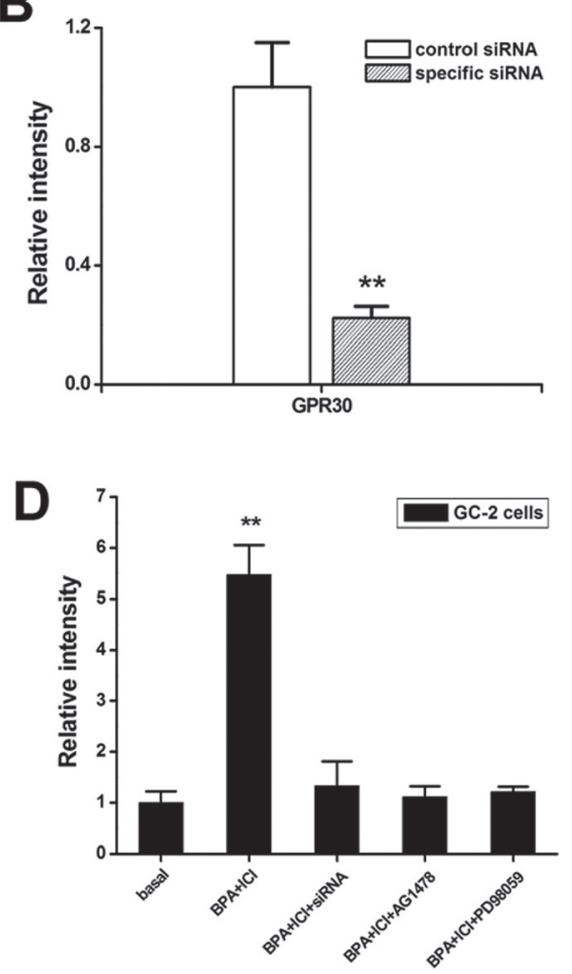

Figure 4: The expression of activated Erk1/2 in GC-2 cells performed by different ways. (A, B) Expression of GPR30 in GC-2 cells transfected with specific siRNA. GC-2 cells were transfected with $100 \mathrm{nM}$ siRNA against GPR30, non-targeting (control siRNA) siRNA as indicated. At $48 \mathrm{~h}$ post transfection, protein was extracted and subjected to a Western blot analysis for GPR30. The levels of b-actin protein were used as loading control. Results are representative of three independent experiments. (C, D) Blocking of Erk1/2 signaling with PD, AG and siRNA against Gpr30. Cells were pretreated with $10 \mu \mathrm{M}$ of ICI, or $10 \mu \mathrm{M}$ PD+ICI or $10 \mu \mathrm{M} \mathrm{AG+ICI} \mathrm{for}$ $30 \mathrm{~min}$ or $\mathrm{Gpr} 30$ siRNA for $48 \mathrm{~h}$, and then treated with $0.1 \mu \mathrm{M}$ BPA for $15 \mathrm{~min}$. The activation of Erk1/2 was examined as shown in Figure 4. D. The figure of Western blot is a representative of three independent experiments. The density of the band for $\mathrm{p}$-Erk $1 / 2$ was normalized with that of total Erk1/2 and the value is shown in the graph (right). ${ }^{* *} P<0.01$, compared to the control.

A

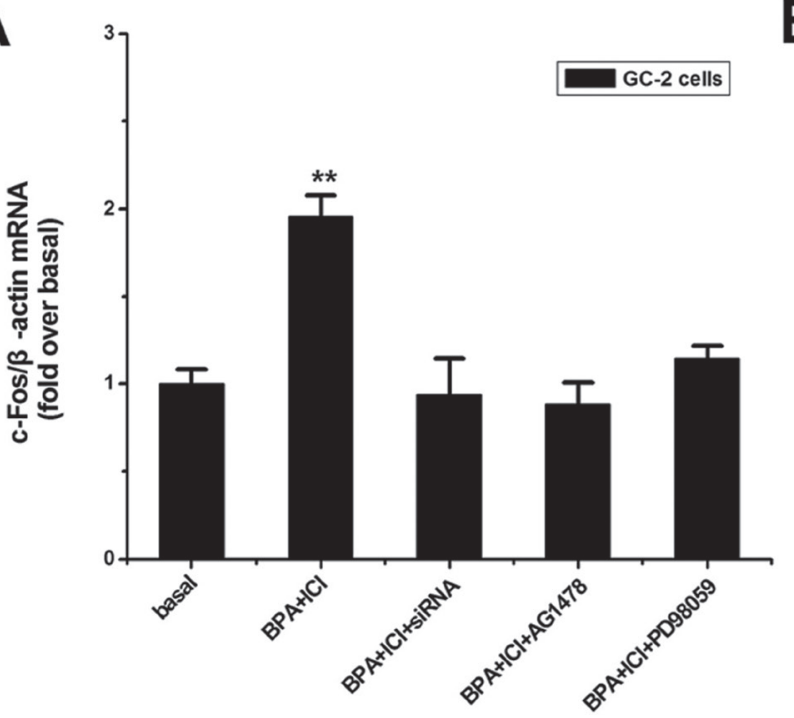

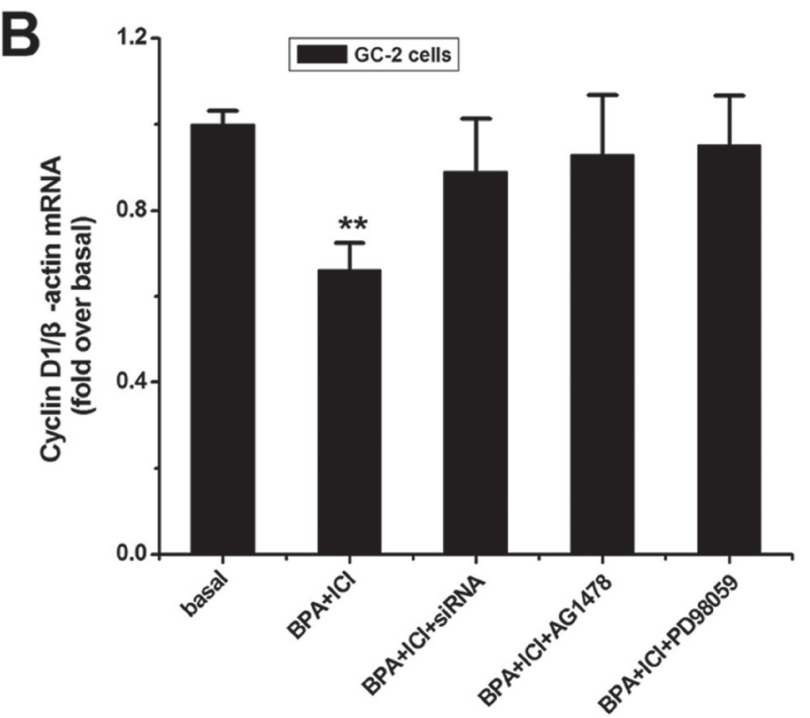

Figure 5: Effects of BPA on the downstream relative genes expression. (A, B) GC-2 cells were treated as described above, Total RNA was extracted for qPCR. c-Fos and Cyclin D1 mRNA expression levels were evaluated following normalization to $\beta$-actin level. The values represent the mean $\pm \mathrm{SD}$ of the data from three independent experiments. $* * P<0.01$. 


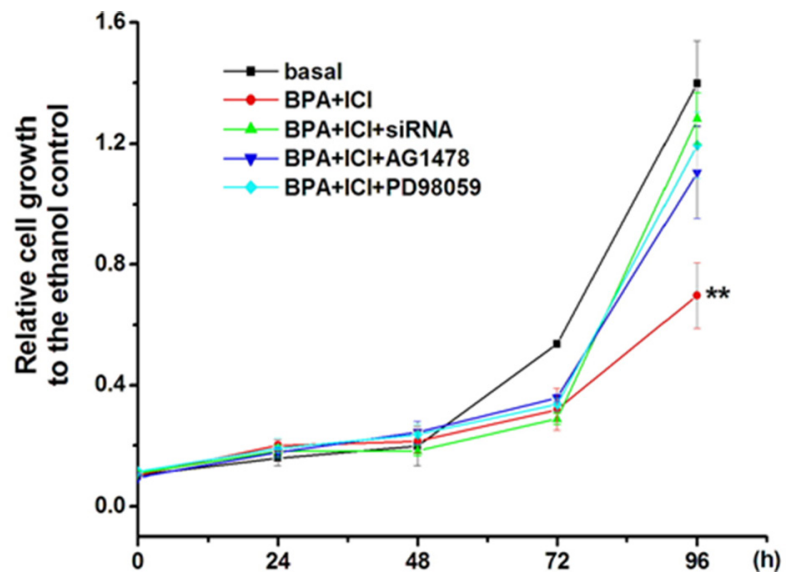

Figure 6: Inhibition of GC-2 cell proliferation by BPA went though EGFR-MAPK pathway mediated by GPR30. GC-2 cells were planted in 96-well plates with a density of 2,000 per well. Incubated with $0.1 \mu \mathrm{M}$ BPA and examined the cell activity every $24 \mathrm{~h}$ using MTT assay. After $72 \mathrm{~h}$ treatment, the account of cells number was less compare to the basal, and $96 \mathrm{~h}$ later, this number disparity was more apparent $(P<0.01)$. In conclusion, the activation of GPR30 was closer to the cell growth inhibition. siRNA, AG and PD prevented from the inhibition. ${ }^{* *} P<0.01$.

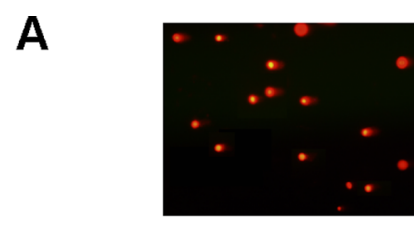

control

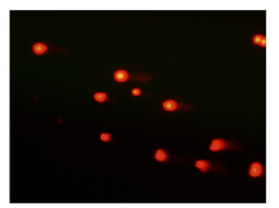

BPA+|Cl+siRNA

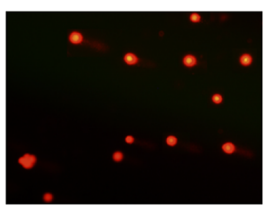

$\mathrm{BPA}+\mid \mathrm{Cl}+\mathrm{AG} 1478$

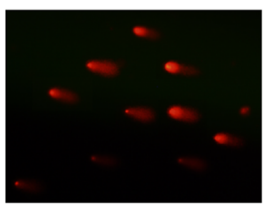

$\mathrm{BPA}+\mathrm{ICl}$

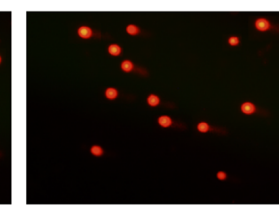

BPA+|C|+PD98059
B

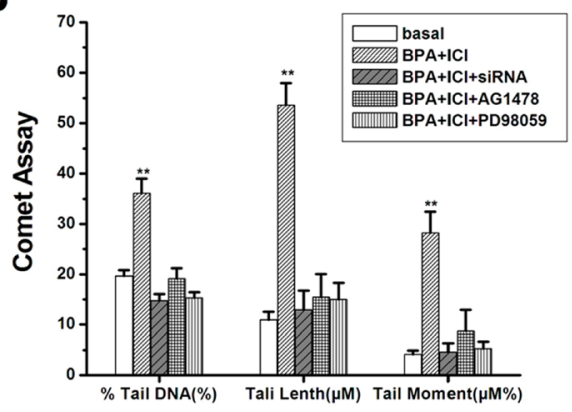

C

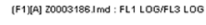

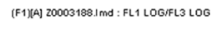
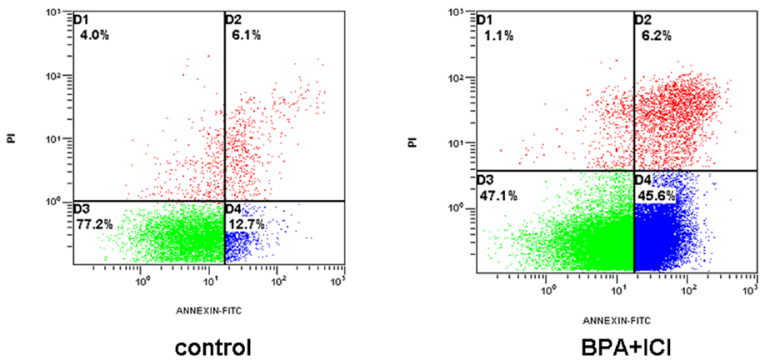

$\mathrm{BPA}+\mid \mathrm{Cl}$

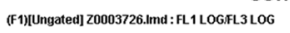

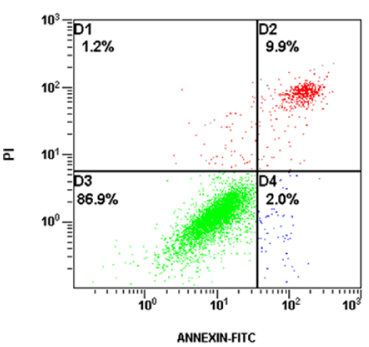

BPA+ICl+siRNA

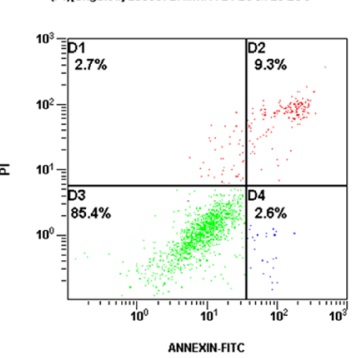

BPA+|Cl+AG1478

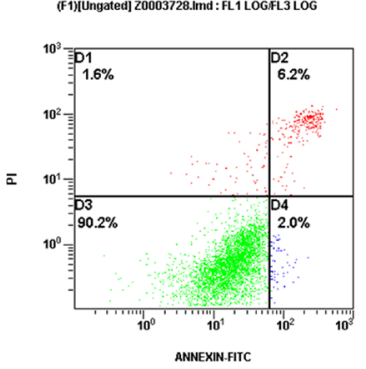

BPA+ICI+PD98059

Figure 7: (A) Comet assay. DNA-damaged induced in different ways as described above in GC-2 cells. (B) The histogram of relative index in Comet assay. (C) Flow cytometry. Apoptosis induced in different ways as described above in GC-2 cells. 
phenyl methyl sulfonyl fluoride, $1 \mu \mathrm{g} / \mathrm{mL}$ pepstatin, $2 \mu \mathrm{g} / \mathrm{mL}$ leupeptin, $5 \mu \mathrm{g} / \mathrm{mL}$ aprotinin). The protein concentration was determined using the Pierce (Rockford, IL) BCA (bicinchoninic acid) protein assay.

Equal amounts of whole protein extract were electrophoresed onto $12 \%$ or $15 \%$ sodium dodecyl sulfate polyacryl amide gel electrophoresis (SDS-PAGE) replicas of gels and then transferred to nitrocellulose membranes (Millipore, Billerica, MA) using a semi-dry transfer cell (Bio-Rad Laboratories, Hercules, CA) at $1 \mathrm{~mA} / \mathrm{cm} 2$ for $2 \mathrm{~h}$. After transferred to polyvinyl difluoride membranes, samples were blocked in 1\% dry milk and incubated overnight with the following primary antibodies

ER $\alpha$ (1:400; Santa Cruz Biotechnology, Santa Cruz, CA), ER $\beta$ (1:3,000; Upstate, Danvers, MA), GPR30 (1:1000; Santa Cruz Biotechnology, Santa Cruz, CA) or GAPDH (1:10,000; Sigma). After incubation with horseradish peroxidase-conjugated secondary antibody (Amersham, Piscataway, NJ), products were developed on film using Super Signal chemiluminescence reagents (Pierce).

The levels of proteins and phosphoproteins were detected with horseradish peroxidase-linked secondary antibodies and revealed using the $\mathrm{ECL}^{\circledR}$ System (GE Healthcare, Milan, Italy).
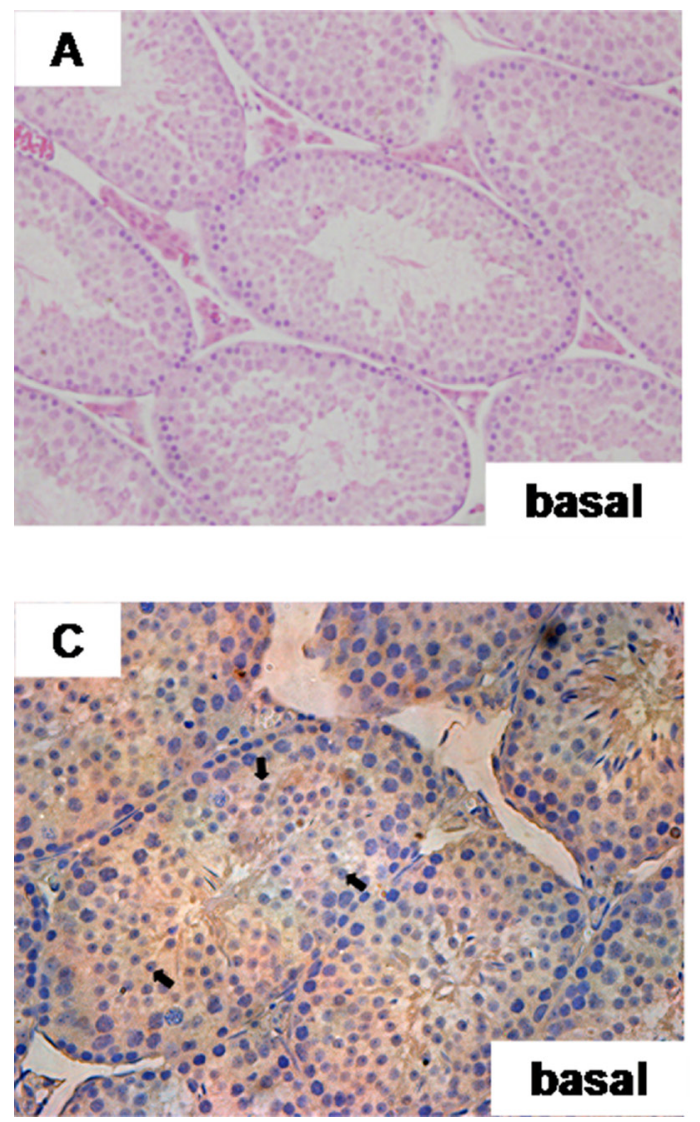

\section{MTT assay}

Cells were plated at a density of 6,000 or 8,000 cells/ well in 96-well plates in plating medium. For the determination of cell growth, treatments were performed for $48 \mathrm{~h}$ in serum-free medium without phenol red. Control cells were treated with the same amount of DMSO (0.1\% DMSO) alone, which never exceeded the concentration of $0.01 \%(\mathrm{vol} / \mathrm{vol})$. The treatment effects on GC-2 cell growth were determined by MTT (3-[4, 5-dimethylhiazol-2-yl]-2, 5-diphenyltetrazolium bromide) assay; In brief, at the end of treatment, $100 \mu \mathrm{l}$ of MTT $(5 \mathrm{mg} / \mathrm{ml}$ in $1 \mathrm{M} \mathrm{PBS}, \mathrm{pH} \mathrm{7.6)}$ was added to each well of 96-well plates and allowed to incubate for $2 \mathrm{~h}$ at $37^{\circ} \mathrm{C}$ in $5 \% \mathrm{CO}_{2}$ air. The optical density (OD) was measured using a microplate reader at $570 \mathrm{~nm}$. MTT was added at a final concentration of $0.5 \mathrm{mg} / \mathrm{mL}$ for $2 \mathrm{hr}$. After medium aspiration, the formazan dye was extracted with DMSO and absorbance was read at $570 \mathrm{~nm}$ using a plate reader (Bio-Tek, Winooski, VT).

\section{Single cell gel electrophoresis (comet assay) \\ $1 \times 10^{6}$ cells were suspended in $1 \mathrm{ml}$ PBS $(137 \mathrm{mM}$, $2.7 \mathrm{mM} \mathrm{KCl}, 10 \mathrm{mM} \mathrm{Na} 2 \mathrm{HPO} 4,2$ mM KH2PO4, PH 7.4).}
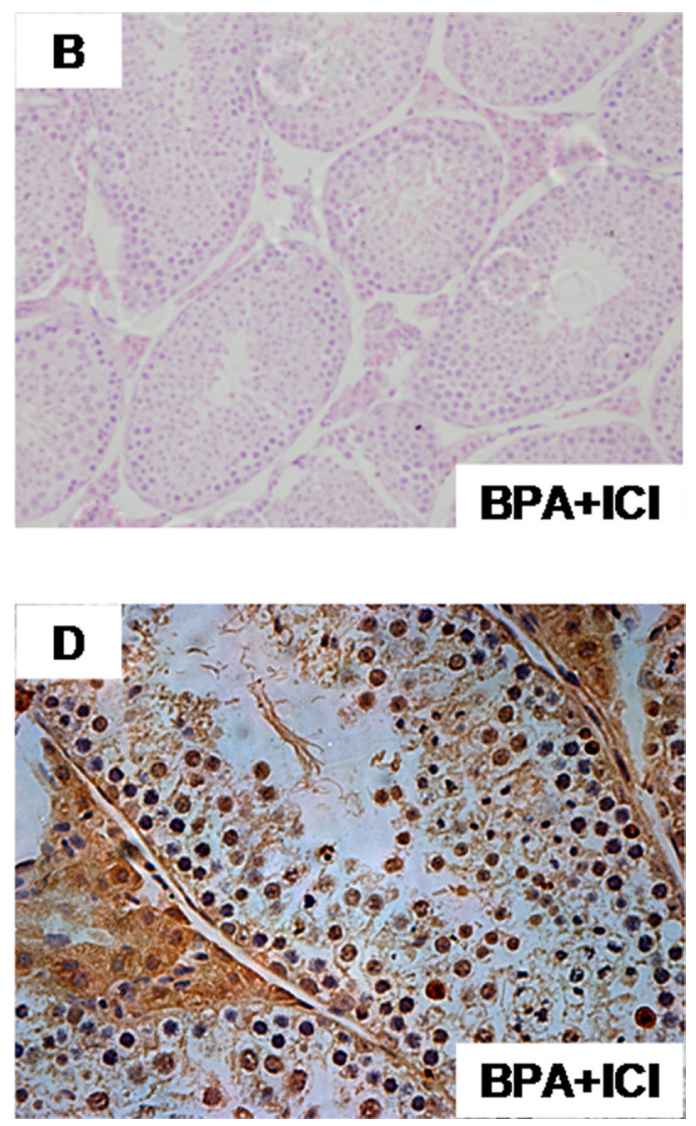

Figure 8: Spermatocytes apoptosis occurred via GRP30-mediated (TUNEL). (A, B) Seminiferous tubules in normal and BPA-treated mouse. (C, D) The apoptosis examined by TUNEL assay. Apoptosis triggered by BPA via GPR30 in spermatogenic cells from mouse testis. The arrow pointed to spermatocytes. 
$10 \mu \mathrm{l}$ suspensions was mixed with $90 \mu \mathrm{l} 1 \%$ low melting agarose and placed onto a slide pre-coated with $1 \%$ low melting agarose. Then the suspension was immediately covered with a clean coverslide and kept for 10 minutes in order to solidification. The coverslide was slightly removed and $500 \mu \mathrm{l}$ lysis buffer $(2.5 \mathrm{M} \mathrm{NaCl}, 100 \mathrm{mM}$ Na2-EDTA, 10mM Tris, PH 10, 1\% Triton X-100) was dropped on the embedded cells for 1.5 hours. After washing in re-stilled water, the slide was placed in a horizontal gel electrophoresis chamber filled with cold electrophoretic buffer $(0.3 \mathrm{mM} \mathrm{NaOH}, 1 \mathrm{mM}$ Na2-EDTA, PH 13) for 25 minutes to make the DNA unwind, and then performed electrophoresis for 25 minutes $(25 \mathrm{~V}, 300 \mathrm{~mA})$. After that, the slide was treated with re-stilled water one time and washed with the residual electrophoretic buffer and neutralization buffer (0.4 M Tris, PH 7.5) 3 times. All the steps were performed in dark and cold condition to prevent additional DNA damage. The slide was stained with ethidium bromide $(20 \mathrm{mg} / \mathrm{ml})$, and then analyzed with a fluorescence microscope (Leica DM IRB) at a magnification of $200 \times$. Digital images were acquired with DP-BSW software (OLYMPUS) and analyzed by the CASP software. More than 100 cells were analyzed for each sample.

\section{Annexin V/propidium lodide assay for apoptosis detection}

Before cells were collected by centrifugation and resuspended in $500 \mu \mathrm{l}$ annexin-binding buffer. The concentration of final cells suspension was approximate $1 \times 10^{6}$ cells, which was determined on a hemocytometer. Each sample was added $5 \mu \mathrm{l}$ of Annexin V-FITC and $10 \mu \mathrm{l}$ of propidium iodide and incubated on ice in the dark for 5 minutes, and then analyzed on a flow cytometer (BD Biocsiences, San Jose, USA). To discriminate between positive and negative group, a non-stained control sample was subjected to flow cytometer acquisition and analyzed to define their cut off. The collected fluorescence for annexin $\mathrm{V}$ was at 530/30 $\mathrm{nm}$ and for PI was at 584/40 nm. Data were analyzed with BD FACSuite ${ }^{\mathrm{TM}}$. Data were collected on more than 10,000 cells per cell sample.

\section{RNA interference}

GPR30 siRNA and non targeting siRNA were purchased from Qiagen. GC-2 cells were plated into $60 \mathrm{~mm}$ dishes at $1 \times 10^{6}$ cells for protein extraction, and into 24 -well plates at $2 \times 10^{5}$ cells/well for proliferation assay and used for transfection $24 \mathrm{~h}$ later. The cells were transfected using the siRNA transfection reagent (Qiagen, Biotechnology) with $10 \mathrm{nM}$ GPR30 or control siRNA according to the manufacturer's instructions. The oligonucleotides used were: 5'-TGGAGTAGTCGCATCCAT-3' for GPR30 and 5'-GATCTCAGC ACGGCAAAT-3' for the scrambled control. Immunoblotting and the quantitative real-time reverse transcription-polymerase chain reaction (qPCR) were then performed. To confirm the specific inhibitory activity, we carried out a Western blot analysis using the antibody against GPR30. For inhibited proliferation experiments, cells were maintained in medium containing the transfection mix for $24 \mathrm{~h}$ and medium was then replaced for the treatment. Proliferation was evaluated $48 \mathrm{~h}$ later.

\section{Immunohistochemistry}

Serial paraffin wax sections of mice testis $(20 \mu \mathrm{m})$ were analyzed using TUNEL assay (Boster, Wuhan, China). Briefly, the sections were incubated with labeling buffer containing TdT and DIG-d-UTP for $120 \mathrm{~min}$ at $37^{\circ} \mathrm{C}$ to incorporate adequately and were then turned to incubate with diluted extraavidin-peroxidase link for another $30 \mathrm{~min}$ at $37^{\circ} \mathrm{C}$, followed by the addition of DAB at room temperature for $30 \mathrm{~min}$. All sections were counterstained with hematoxylin. We scored the cells of which the expression developed a brown color as positive ones.

\section{Statistical analysis}

Statistical differences were determined by one-way analysis of variance followed by Newman-Keuls post hoc analysis. $P$-Values $<0.05$ were considered significant. All experiments were performed at least three times.

\section{ACKNOWLEDGMENTS AND FUNDING}

The authors are appreciative to the donors, whose names were not included in the author list, but who participated in this program. This work was funded by National Science Foundation of China (No. 81670869) and The Science and Technology Leading Talent Research Foundation of Zhengzhou (No. 131PLJRC657).

\section{CONFLICTS OF INTEREST}

There is no conflicts of interest between the authors.

\section{REFERENCES}

1. White R, Jobling S, Hoare SA, Sumpter JP, Parker MG. Environmentally persistent alkylphenolic compounds are estrogenic. Endocrinology. 1994; 135:175-82.

2. Nimrod AC, Benson WH. Environmental estrogenic effects of alkylphenol ethoxylates. Crit Rev Toxicol. 1996; 26:335-64.

3. Roepke TA, Snyder MJ, Cherr GN. Estradiol and endocrine disrupting compounds adversely affect development of sea urchin embryos at environmentally relevant concentrations. Aquat Toxicol. 2005; 71:155-73.

4. Tyler CR, Jobling S, Sumpter JP. Endocrine disruption in wildlife: a critical review of the evidence. Crit Rev Toxicol. 1998; 28:319-61. 
5. Segner H, Caroll K, Fenske M, Janssen CR, Maack G, Pascoe D, Schäfers C, Vandenbergh GF, Watts M, Wenzel A. Identification of endocrine-disrupting effects in aquatic vertebrates and invertebrates: report from the European IDEA project. Ecotoxicol Environ Saf. 2003; 54:302-14.

6. Jobling S, Casey D, Rodgers-Gray T, Oehlmann J, SchulteOehlmann U, Pawlowski S, Baunbeck T, Turner AP, Tyler CR. Comparative responses of molluses and fish to environmental estrogens and an estrogenic effluent. Aquat Toxicol. 2003; 65:205-20.

7. Ikezuki Y, Tsutsumi O, Takai Y, Kamei Y, Taketani Y. Determination of bisphenol A concentrations in human biological fluids reveals significant early prenatal exposure. Hum Reprod. 2002; 17:2839-41.

8. Welshons WV, Nagel SC, vom Saal FS. Large effects from small exposures. III. Endocrine mechanisms mediating effects of bisphenol A at levels of human exposure. Endocrinology. 2006 (Suppl); 147:S56-69.

9. Tsai WT. Human health risk on environmental exposure to Bisphenol-A: a review. J Environ Sci Health C Environ Carcinog Ecotoxicol Rev. 2006;24:225-55.

10. Vandenberg LN, Hauser $R$, Marcus $M$, Olea $N$, Welshons WV. Human exposure to bisphenol A (BPA). Reprod Toxicol. 2007; 24:139-77.

11. Geens T, Roosens L, Neels H, Covaci A. Assessment of human exposure to Bisphenol-A, Triclosan and Tetrabromobisphenol-A through indoor dust intake in Belgium. Chemosphere. 2009; 76:755-60.

12. Brotons JA, Olea-Serrano MF, Villalobos M, Pedraza V, Olea N. Xenoestrogens released from lacquer coatings in food cans. Environ Health Perspect. 1995; 103:608-12.

13. Lambert C, Larroque M, Subirats JT, Gérard JF. Foodcontact epoxy resin: co-variation between migration and degree of cross-linking. Part II. Food Addit Contam. 1998; 15:318-28.

14. Calafat AM, Ye X, Wong LY, Reidy JA, Needham LL. Exposure of the U.S. population to bisphenol A and 4-tertiary-octylphenol: 2003-2004. Environ Health Perspect. 2008; 116:39-44.

15. Wetherill YB, Akingbemi BT, Kanno J, McLachlan JA, Nadal A, Sonnenschein C, Watson CS, Zoeller RT, Belcher SM. In vitro molecular mechanisms of bisphenol A action. Reprod Toxicol. 2007; 24:178-98.

16. Takai Y, Tsutsumi O, Ikezuki Y, Hiroi H, Osuga Y, Momoeda M, Yano T, Taketani Y. Estrogen receptormediated effects of a xenoestrogen, bisphenol A, on preimplantation mouse embryos. Biochem Biophys Res Commun. 2000; 270:918-21.

17. Hunt PA, Koehler KE, Susiarjo M, Hodges CA, Ilagan A, Voigt RC, Thomas S, Thomas BF, Hassold TJ. Bisphenol a exposure causes meiotic aneuploidy in the female mouse. Curr Biol. 2003; 13:546-53.

18. Takeuchi T, Tsutsumi O, Ikezuki Y, Takai Y, Taketani Y. Positive relationship between androgen and the endocrine disruptor, bisphenol A, in normal women and women with ovarian dysfunction. Endocr J. 2004; 51:165-9.

19. Richter CA, Birnbaum LS, Farabollini F, Newbold RR, Rubin BS, Talsness CE, Vandenbergh JG, Walser-Kuntz DR, vom Saal FS. In vivo effects of bisphenol A in laboratory rodent studies. Reprod Toxicol. 2007; 24:199-224.

20. Bouskine A, Nebout M, Brücker-Davis F, Benahmed M, Fenichel P. Low doses of bisphenol A promote human seminoma cell proliferation by activating PKA and PKG via a membrane G-protein-coupled estrogen receptor. Environ Health Perspect. 2009; 117:1053-8.

21. Salian S, Doshi T, Vanage G. Neonatal exposure of male rats to Bisphenol A impairs fertility and expression of sertoli cell junctional proteins in the testis. Toxicology. 2009; 265:56-67.

22. Salian S, Doshi T, Vanage G. Perinatal exposure of rats to Bisphenol A affects the fertility of male offspring. Life Sci. 2009; 85:742-52.

23. Li D, Zhou Z, Qing D, He Y, Wu T, Miao M, Wang J, Weng X, Ferber JR, Herrinton LJ, Zhu Q, Gao E, Checkoway H, et al. Occupational exposure to bisphenol-A (BPA) and the risk of self-reported male sexual dysfunction. Hum Reprod. 2010; 25:519-27.

24. Akingbemi BT. Estrogen regulation of testicular function. Reprod Biol Endocrinol. 2005; 3:51.

25. Hess RA, Bunick D, Lee KH, Bahr J, Taylor JA, Korach KS, Lubahn DB. A role for oestrogens in the male reproductive system. Nature. 1997; 390:509-12.

26. Carreau S, Delalande C, Silandre D, Bourguiba S, Lambard S. Aromatase and estrogen receptors in male reproduction. Mol Cell Endocrinol. 2006; 246:65-8.

27. Couse JF, Korach KS. Estrogen receptor-alpha mediates the detrimental effects of neonatal diethylstilbestrol (DES) exposure in the murine reproductive tract. Toxicology. 2004; 205:55-63.

28. Nelson JA. Effects of dichlorodiphenyltrichloroethane (DDT) analogs and polychlorinated biphenyl (PCB) mixtures on 17 beta- $(3 \mathrm{H})$ estradiol binding to rat uterine receptor. Biochem Pharmacol. 1974; 23:447-51.

29. Loomis AK, Thomas P. Binding characteristics of estrogen receptor (ER) in Atlantic croaker (Micropogonias undulatus) testis: different affinity for estrogens and xenobiotics from that of hepatic ER. Biol Reprod. 1999; 61:51-60.

30. Korach KS, Sarver P, Chae K, McLachlan JA, McKinney JD. Estrogen receptor-binding activity of polychlorinated hydroxybiphenyls: conformationally restricted structural probes. Mol Pharmacol. 1988; 33:120-6.

31. Laudet V, Hänni C, Coll J, Catzeflis F, Stéhelin D. Evolution of the nuclear receptor gene superfamily. EMBO J. 1992; 11:1003-13.

32. Mangelsdorf DJ, Thummel C, Beato M, Herrlich $\mathrm{P}$, Schütz G, Umesono K, Blumberg B, Kastner P, Mark M, Chambon P, Evans RM. The nuclear receptor superfamily: the second decade. Cell. 1995; 83:835-9. 
33. Ascenzi P, Bocedi A, Marino M. Structure-function relationship of estrogen receptor alpha and beta: impact on human health. Mol Aspects Med. 2006; 27:299-402.

34. Khurana S, Ranmal S, Ben-Jonathan N. Exposure of newborn male and female rats to environmental estrogens: delayed and sustained hyperprolactinemia and alterations in estrogen receptor expression. Endocrinology. 2000; 141:4512-7.

35. Singleton DW, Feng Y, Yang J, Puga A, Lee AV, Khan SA. Gene expression profiling reveals novel regulation by bisphenol-A in estrogen receptor-alpha-positive human cells. Environ Res. 2006; 100:86-92.

36. Bredhult C, Bäcklin BM, Olovsson M. Effects of some endocrine disruptors on the proliferation and viability of human endometrial endothelial cells in vitro. Reprod Toxicol. 2007; 23:550-9.

37. Kuiper GG, Lemmen JG, Carlsson B, Corton JC, Safe SH, van der Saag PT, van der Burg B, Gustafsson JA. Interaction of estrogenic chemicals and phytoestrogens with estrogen receptor beta. Endocrinology. 1998; 139:4252-63.

38. Levin ER. Integration of the extranuclear and nuclear actions of estrogen. Mol Endocrinol. 2005; 19:1951-9.

39. Filardo EJ, Quinn JA, Frackelton AR Jr, Bland KI. Estrogen action via the $\mathrm{G}$ protein-coupled receptor, GPR30: stimulation of adenylyl cyclase and cAMP-mediated attenuation of the epidermal growth factor receptor-toMAPK signaling axis. Mol Endocrinol. 2002; 16:70-84.

40. Maggiolini M, Vivacqua A, Fasanella G, Recchia AG, Sisci D, Pezzi V, Montanaro D, Musti AM, Picard D, Andò S. The G protein-coupled receptor GPR30 mediates c-fos up-regulation by 17 beta-estradiol and phytoestrogens in breast cancer cells. J Biol Chem. 2004; 279:27008-16.

41. Thomas P, Pang Y, Filardo EJ, Dong J. Identity of an estrogen membrane receptor coupled to a $\mathrm{G}$ protein in human breast cancer cells. Endocrinology. 2005; 146:624-32.

42. Revankar CM, Cimino DF, Sklar LA, Arterburn JB, Prossnitz ER. A transmembrane intracellular estrogen receptor mediates rapid cell signaling. Science. 2005; 307:1625-30.

43. Thomas P, Dong J. Binding and activation of the seventransmembrane estrogen receptor GPR30 by environmental estrogens: a potential novel mechanism of endocrine disruption. J Steroid Biochem Mol Biol. 2006; 102:175-9.

44. Carmeci C, Thompson DA, Ring HZ, Francke U, Weigel RJ. Identification of a gene (GPR30) with homology to the G-protein-coupled receptor superfamily associated with estrogen receptor expression in breast cancer. Genomics. 1997; 45:607-17.

45. Lapensee EW, Tuttle TR, Fox SR, Ben-Jonathan N. Bisphenol A at low nanomolar doses confers chemoresistance in estrogen receptor-alpha-positive and -negative breast cancer cells. Environ Health Perspect. 2009; 117:175-80.
46. Dong S, Terasaka S, Kiyama R. Bisphenol A induces a rapid activation of Erk1/2 through GPR30 in human breast cancer cells. Environ Pollut. 2011; 159:212-8.

47. Bulayeva NN, Watson CS. Xenoestrogen-induced ERK-1 and ERK-2 activation via multiple membrane-initiated signaling pathways. Environ Health Perspect. 2004; 112:1481-7.

48. Shaulian E, Karin M. AP-1 as a regulator of cell life and death. Nat Cell Biol. 2002; 4:E131-6.

49. Chan QK, Lam HM, Ng CF, Lee AY, Chan ES, Ng HK, Ho SM, Lau KM. Activation of GPR30 inhibits the growth of prostate cancer cells through sustained activation of Erk1/2, c-jun/c-fos-dependent upregulation of p21, and induction of $\mathrm{G}(2)$ cell-cycle arrest. Cell Death Differ. 2010; 17:1511-23.

50. Safe SH, Pallaroni L, Yoon K, Gaido K, Ross S, McDonnell D. Problems for risk assessment of endocrineactive estrogenic compounds. Environ Health Perspect. 2002 (Suppl 6); 110:925-9.

51. vom Saal FS, Hughes C. An extensive new literature concerning low-dose effects of bisphenol A shows the need for a new risk assessment. Environ Health Perspect. 2005; 113:926-33.

52. Takai Y, Tsutsumi O, Ikezuki Y, Kamei Y, Osuga Y, Yano T, Taketan Y. Preimplantation exposure to bisphenol A advances postnatal development. Reprod Toxicol. 2001;15:71-4.

53. Qian W, Zhu J, Mao C, Liu J, Wang Y, Wang Q, Liu Y, Gao R, Xiao H, Wang J. Involvement of CaM-CaMKIIERK in bisphenol A-induced Sertoli cell apoptosis. Toxicology. 2014;324:27-34.

54. Sheng ZG, Huang W, Liu YX, Zhu BZ. Bisphenol A at a low concentration boosts mouse spermatogonial cell proliferation by inducing the $\mathrm{G}$ protein-coupled receptor 30 expression. Toxicol Appl Pharmacol. 2013; 267:88-94.

55. Ge LC, Chen ZJ, Liu HY, Zhang KS, Liu H, Huang HB, Zhang G, Wong CK, Giesy JP, Du J, Wang HS. Involvement of activating ERK1/2 through $\mathrm{G}$ protein coupled receptor 30 and estrogen receptor $\alpha / \beta$ in low doses of bisphenol $\mathrm{A}$ promoting growth of Sertoli TM4 cells. Toxicol Lett. 2014; 226:81-9.

56. Filardo EJ, Quinn JA, Bland KI, Frackelton AR Jr. Estrogen-induced activation of Erk-1 and Erk-2 requires the G protein-coupled receptor homolog, GPR30, and occurs via trans-activation of the epidermal growth factor receptor through release of HB-EGF. Mol Endocrinol. 2000; 14:1649-60.

57. Sherr CJ, Roberts JM. Living with or without cyclins and cyclin-dependent kinases. Genes Dev. 2004; 18:2699-711. 